\title{
STUDI KOMPARATIF TENTANG METODE MENGHAFAL AL QUR'AN ANTARA PP. PUTRI AL MUNAWIR KOMPLEK “Q” DENGAN PP. PUTRI ALI MAKSUM KRAPYAK BANTUL YOGYAKARTA
}

\author{
Sukati \\ Prodi PGMI STIA Alma Ata Yogyakarta \\ Email: kanzaajiba@yahoo.com
}

\begin{abstract}
This study aims to determine: Qur'an memorization method used in PP. Daughter Al Munawwir Complex " $Q$ " and the PP. Daughter Ali Maksum Krapyak Bantul, Yogyakarta, differences and similarities, factors that support and binder the results achieved in memorizing the Koran in both the PP. Daughter Al Munawwir Complex "Q" or PP. Daughter Ali Maksum Krapyak Bantul, Yogyakarta.

This research includes a comparative descriptive research with 59 students in PP Putri Al Munawwir Krapyak Komplek Q and 61 students PP Putri Ali Maksum. Collecting data using observation method, method Interview (Interview), Methods Questionnaire, and Documentation. And data analysis using qualitative and quantitative methods.

The results showed that: The method of teaching to memorize the Qur'an used in PP. Daughter Al Munawwir Complex " $Q$ " is Tabfidz method with Qiro'ati method, method in memorize of juz amma binnadzor method juz 1, musyafadah method with one by one. Takrir method with musyafahab method in pairs, group method, estafet method, seaman method. Methods of proof with musyafahah with pairwise method, the method group, a relay method, the method Semaan. Teaching method in memorize of Qur'an used in PP Putri Ali Maksum are Method Tahfidz with binnadzri method, Method musyafahah with five-five. Methods of proof with musyafahah method with one by one, Methods jam'u al, Methods istima'i (Semaan) Friday legi, pray method. The diffeences of those located in the implementation and the similarities located using two methos, tabfidz method and takrir method. Factors that support in memorize of Quran in PP Putri Al Munawwir komplek Q: workship Allah, and preserve purity of Quran, 67.80\%; memorize when there is free time 49,15\% memorize because of support by situation and condition 47,46\%. While factor that support in memorize of Quran 65,57\%; memorize when the mind is quiet 59,02\% and situation that support 44,26\%.
\end{abstract}


Factors that block in PP Putri Al Munawwir komplek Q, sometimes the student has difficulties to memorize of Quran and can not consentrate (59,02\%) and they must to repeat the memoriez of Quran 37,70\%. the result achieved in memorize of Quran in PP Putri Al Munawwir complex Q in daily routine, not more than 64,61\% and they don't have a brave listened by the master of Quran yet. While in PP Putri Ali Maksum in daily routine, not more than 65,57\% and they a brave listened by the master of Quran.

Keyword: comparative, memorization method

\section{PENDAHULUAN}

Al-Qur'an adalah kalam Allah SWT yang diturunkan kepada Nabi Muhammad SAW sebagai pedoman hidup bagi kaum muslimin. Hal ini mengandung arti bahwa kitab suci Al-Qur'an harus dibaca, dihafalkan, difahami dan diamalkan ajaran-ajaran yang terkandung di dalamnya oleh umat Islam di seluruh dunia.

Di dalam mempelajari, mengamalkan dan menyebarkan ajaran-ajaran Al-Qur'an, Pondok Pesantren tersebut sebagai lembaga pendidikan Islam mempunyai peranan yang sangat besar bagi dakwah Islam dan bagi bangsa, serta negara. Namun tidak semua pemeluk agama Islam sanggup menghafal dan tidak semua kitab suci dapat dihafalkan kecuali kitab suci Al-Qur'an dan hamba-hamba yang terpilih yang sanggup menghafalnya. Hal ini terbukti oleh firman Allah SWT yang berbunyi sebagai berikut:

Artinya : Kemudian kitab itu Kami wariskan kepada orang yang Kami pilih di antara hamba-hamba Kami. ${ }^{1}$

Al-Qur'an memperkenalkan diri dengan berbagai ciri dan sifatnya. Salah satunya ialah bahwa ia merupakan salah satu kitab suci yang dijamin keasliannya oleh Allah SW'T sejak diturunkan kepada Nabi Muhammad SAW hingga sekarang bahkan sampai hari kemudian. Sebagaimana ditegaskan dalam firman Allah SWT:

Artinya : Sesungguhnya Kamilah yang menurunkan Al-Qur'an dan sesungguhnya Kami benar-benar memeliharanya. ${ }^{2}$

Allah memelihara Al-Quran dengan memberikan amanat kepada orang yang dikehendaki-Nya sehingga mereka dapat menghafal seluruh isi kandungan Al-Qur'an.

${ }^{1}$ Departemen Agama RI, Al Quran dan Terjemahnya, (Jakarta : Proyek Pengadaan Kitab Suci Al-Qur'an, 1985), hal. 700.

${ }^{2}$ Ibid, hal. 391. 
Pada masa Rosulullah SAW, Al-Qur'an diajarkan secara langsung pada sahabat dengan cara menghafalkan dan ada yang menuliskannya di pelepah kurma, tulang dan sebagainya. Sehingga dalam kehidupan sehari-hari sudah tercipta suasana Qur'ani, setiap saat Al-Qur'an selalu dibacanya sehingga, memudahkan dalam hafalan. Menghafal Al-Qur'an tidak mudah jika tidak disertai kebersihan hati, kesungguhan, keuletan dan kesabaran karena ayat-ayat dalam Al-Qur'an banyak yang terdapat kemiripan antara ayat yang satu dengan ayat yang lain. Seperti firman Allah SWT:

Artinya : Allah telah menurunkan perkataan yang paling baik (yaitu) AlQur'an yang serupa (mutu ayat-ayatnya) lagi berulang-ulang, gemetar karenanya kulit orang yang takut kepada Tuhannya, kemudian menjadi tenang kulit hati mereka di waktu mengingat Allah"3

Kemudian ayat-ayat yang pernah dihafalpun juga mudah bahkan bisa hilang dari ingatannya. Semacam ini membuktikan bahwa menjaga hafalan Al-Qur'an adalah tidak mudah. Sebagaimana sabda Rosulullah SAW sebagai berikut:

Artinya: Diriwayatkan oleh Abi Musa Al-Asy'ari r.a. dari Nabi Muhammad SAW beliau bersabda, "Jagalah selalu hafalan Al-Qur'an demi Dzat yang menguasai pwaku ada pada rengkuhan-Nya, sesungguhnya itu lebih cepat lepasnya ketimbang seekor unta pada tambatannya”. (H.R. Al-Bukhori Muslim). ${ }^{4}$

Untuk menjaga hal-hal seperti di atas, maka perlu mendapat perhatian bagi penghafal Al-Qur'an untuk selalu memelihara hafalannya.

Dengan demikian, orang-orang menghafal Al-Qur'an pada hakekatnya adalah orang-orang pilihan yang sengaja dipilih oleh Allah SWT. untuk menjaga kemurnian kitab suci-Nya. Bukti ayat diatas telah memberikan kesadaran umat Islam di Indonesia terhadap pentingnya menjaga kelestarian Al-Qur'an dan kemurnian Al-Qur'an. Hal ini sudah terealisir dengan berdirinya lembaga pendidikan Al-Qur'an yang bersifat non formal, dengan cara menghafal, memahami dan menafsirkan salah satunya adalah PP. Putri Al Munawwir Komplek “Q” dan PP. Putri Ali Maksum dalam memberikan perhatiannya terhadap pelestarian Al-Qur'an. Kedua Pondok Pesantren tersebut memberikan kesempatan bagi para santri yang mempunyai kemauan dan kemampuan untuk menghafal Al-Qur'an dan memiliki latar belakang yang sama yaitu mengelola lembaga pendidikan menghafal Al-Qur'an bahkan di dalamnya banyak mahasiswa yang ikut serta dalam menghafal Al-Qur'an.

\section{${ }^{3}$ Ibid, hal. 749.}

${ }^{4} \mathrm{Al}-\mathrm{Hafidz}$ Abi Muhammad Zakiyuddin 'Abdul 'Adzim bin 'Abdul Qowi Al-Mundziri, Targhib wa Tarbib Minal Hadits Syarif Juz 2, (Beirut: Dar Al-Fikr, 1414 H/1993 M), hal. 223. 
Selain menghafal Al-Qur'an santri diwajibkan untuk mengikuti pengajian yang berhubungan dengan hafalannya seperti pengajian di PP. Putri Al Munawwir Komplek "Q" yaitu kitab At Tibyan fi Adabil Hamalatil Qur'an, Kitab Nashoihul 'Ibad dan Kitab Kabair. Sedangkan di PP. Putri Ali Maksum pengajiannya menggunakan kitab Fat'ul Mu'in dan Fat'ul Qorib. Melihat kesibukan santri tahfidz yang sangat padat tersebut secara rasional sulit untuk mencapai hasil hafalan yang baik dan lancar, apalagi sampai selesai 30 juz, dan prestasi yang diperoleh di sekolah formalnya tidak kalah dengan santri lain. Oleh karena itu, penulis sangat tertarik untuk meneliti dua lembaga tersebut sebagai bahan penelitian lapangan. Hal yang membuat penulis tertarik adalah mayoritas out put yang dihasilkan dari dua lembaga tersebut berkualitas. Akan tetapi metode yang digunakan di PP. Putri Al Munawwir Komplek "Q" tidak dapat menghasilkan santri untuk semaan sendiri sedangkan di PP. Putri Ali Maksum dapat menghasilkan santri semaan sendiri.

Dalam proses pendidikan, metode sangat penting dalam kegiatan belajar mengajar santri untuk mencapai berbagai jenis tujuan, sebagaimana yang dikatakan oleh Prof Dr. Winarno Surakhmad, bahwa seorang guru yang sangat miskin atau mungkin tidak mengetahui adanya metode itu akan berusaha mencapai tujuannya dengan jalan yang tidak wajar. Hasil pengajaran yang serupa ini selalu menyedihkan, guru akan menderita, dan murid demikian. Akan timbul masalah disiplin, rendahnya mutu pelajaran, kurangnya minat anak-anak dan tidak adanya perhatian dan kesungguhan belajar. ${ }^{5}$

Penggunaan metode yang tepat dan bervariasi akan dapat dijadikan sebagai alat motivasi ekstrinsik dalam kegiatan belajar mengajar di lembagalembaga pendidikan baik formal maupun non formal.

Dengan demikian penulis perlu mengetahui metode apa yang digunakan untuk menghafal Al-Qur'an dan bagaimana, aplikasinya, dari metode tersebut. Sehingga penulis nantinya dapat menemukan sejauh mana perbedaan dan persamaan metode menghafal Al-Qur'an yang digunakan di kedua pondok pesantren tersebut.

\section{METODE PENELITIAN}

Jenis penelitian ini merupakan penelitian populasi karenanya jumlahnya terbatas yaitu yang terdiri dari santri penghafal Al-Qur'an yang berdomisili di PP. Putri AI Munawwir Komplek "Q" yang berjumlah kurang lebih 59 santri dan PP. Putri Ali Maksum "Q", yang berjumlah kurang lebih 61 santri.

${ }^{5}$ Muhammad Zein, Metodologi Pengajaran Agama, (Yogyakarta : AK Group \& Indra, 1975), hal. 168. 
Metode pengumpulan data yang digunakan dalam penelitian ini terdiri dari metode observasi, metode interview (wawancara), metode kuesioner, dan dokumentasi.

Metode analisis data yang digunakan dalam penelitian ini adalah:

\section{Metode kualitatif}

Metode ini digunakan untuk menganalisis data yang digambarkan dengan kata-kata atau kalimat yang diperoleh dari hasil penelitian untuk mendapatkan kesimpulan.

Dalam penganalisaan data tersebut penulis menggunakan dua macam metode pendekatan yaitu:

Metode Induktif yaitu berangkat dari fakta-fakta yang khusus, peristiwaperistiwa yang konkret, kemudian dari fakta-fakta atau peristiwa-peristiwa yang konkret itu ditarik generalisasi-generalisasi yang mempunyai sifat umum.

Metode Deduktif yaitu perangkat dan pengetahuan yang sifatnya umum, dan bertitik-tolak pada pengetahuan yang umum itu kita hendak menilai suatu kejadian yang khusus. ${ }^{6}$

\section{Metode Kuantitatif}

Metode ini digunakan untuk menganalisis data-data yang berwujud angkaangka atau data yang dapat dihitung dengan angka yaitu dengan menggunakan statistik kemudian memberikan suatu interpretasi berdasarkan tabel statistik.

Adapun pengertian metode statistik menurut Prof Dr. Sutrisno Hadi, M.A. adalah: Statistik berarti cara-cara tertentu yang perlu ditempuh dalam rangka mengumpulkan, menyusun atau mengatur, menyajikan, menganalisa dan memberikan interpretasi terhadap sekumpulan bahan keterangan yang berupa angka, demikian rupa sehingga kumpulan bahan keterangan yang berupa angka itu dapat berbicara atau dapat memberikan pengertian dan makna tertentu. yaitu dengan menggunakan rumus statistik sebagai berikut:

$$
\mathrm{P}=\underset{\mathrm{N}}{\mathrm{f}} \mathrm{x} 100 \%
$$

Keterangan:

$\mathrm{f} \quad=$ Frekuensi yang sedang dicari persentasenya

$\mathrm{N}=$ Number of cases (Jumlah frekuensi/banyaknya individu)

$\mathrm{P} \quad=$ Angka persentase. ${ }^{8}$

'Sutrisno Hadi, Metodologi Research Jilid II (Yogyakarta: Andi Offset, 1998), hal. 42

${ }^{7}$ Anas Sudijono, Pengantar Statistik Pendidikan (Jakarta: Rajawali, 1992), hal. 3.

${ }^{8}$ Ibid, hal. 41. 
Dalam penelitian ini penulis menggunakan metode analisis deskriptif komparatif yaitu penulis berusaha menggambarkan hasil penelitian berdasarkan data yang terkumpul kemudian dibandingkan antara metode yang digunakan di PP. Putri Al Munawwir Komplek "Q" dengan PP. Putri Ali Maksum.

\section{HASIL PENELITIAN}

\section{Aplikasi Metode Menghafal Al-Qur'an Bagi Santri di PP. Putri Al Munawwir Komplek “Q” Krapyak Bantul Yogyakarta.}

\section{Macam-macam Metode Menghafal Al-Qur'an}

Metode menghafal Al-Qur'an bagi santri pada dasarnya terbagi menjadi dua bagian yaitu metode tahfidz dan takrir. Yang mana satu sama yang lainnya tidak dapat dipisah-pisahkan.

Untuk lebih memperkuat dalam hasil penelitian ini, dalam menghafal penggunaan metode tahfidz dan takrir sebagaimana disebutkan mereka dalam menjawab kuesioner metode apa yang anda gunakan dalam menghafal Al-Qur'an? Sebagai jawabannya bahwa yang menggunakan metode tahfidz saja adalah $13,56 \%$, metode takrir 5,08\%, metode keduanya sebesar 81, 36\%.

Berdasarkan hasil jawaban tersebut, maka dapat disimpulkan bahwa santri PP. Putri Al Munawwir Komplek "Q" menggunakan metode tahfidz dan takrir dalam menghafal Al-Qur'an.

\section{Metode Tahfidz}

Untuk dapat mengetahui santri dalam menghafal Al-Qur'an di PP. Putri Al Munawwir Komplek "Q" dapat dilihat dari jawaban santri atas pertanyaan kapan anda bertahfidz? Mereka memberi jawaban bahwa guru siap menyimak setoran dan santri siap menyetorkan hafalannya kepada guru ini mencapai $15,25 \%$, sedang yang setiap hari sebanyak $71,19 \%$, sementara yang dua hari sekali yaitu $20,34 \%$.

Dalam wawancara penulis dengan wakil ketua asrama tahfidz yaitu Maunah Usman, dia mengatakan bahwa pelaksanaan metode tahfidz dalam PP. Putri Al Munawwir Komplek "Q" melalui beberapa metode pengajaran adalah sebagai berikut:

\section{Metode Qiro'ti}

Metode ini dilaksanakan ketika santri ingin menghafalkan Al-Qur'an, maka harus belajar membaca Qiro'ati terlebih dahulu mulai dari jilid 1 sampai dengan jilid 6. dan caranya dari jilid 1 dibaca sampai selesai, kemudian ujian jilid 1 untuk kenaikan jilid 2, begitu seterusnya hingga khatam jilid 6 . 
Metode ini dilaksanakan juga untuk mengetahui tingkat kemampuan santri mengenai makhorijul hurufnya, sifatul hurufnya. Sehingga diharapkan nantinya santri dapat menghafal Al-Qur'an dengan baik dan benar.

\section{Metode Menghafal Juz 'Amma}

Metode ini dilaksanakan guna untuk melihat kemampuan menghafalnya dan untuk mempraktikkan metode Qiro'ati, sehingga santri wajib menghafalkan Juz `amma terlebih dahulu dan disetorkan kepada Ibu Nyai Hj. Khusnul Khotimah dan tanpa harus dibatasi berapa banyak hafalan yang disetorkan kepadanya, tergantung kemampuan dan kemauan dari santri itu sendiri.

\section{Metode Bin Nadzor juz 1}

Metode ini dilaksanakan sebelum santri menghafalkan juz 1, maka terlebih dahulu la harus mengikuti metode Bin Nadzor ini. Karena metode ini digunakan untuk menjaga bacaan yang sudah diterapkan di dalam metode Qiro'ati. Dan ustadzah yang mendapat kepercayaan untuk mengajar sama dengan ustadzah yang mengajar Qiro'ati. Setelah selasai Bin Nadzor juz 1 santri baru diperbolehkan untuk menghafalkan Al-Qur'an. ${ }^{9}$

\section{Metode Musyafahah}

Metode ini dilaksanakan setelah santri mendapatkan izin dari pengasuh untuk mengikuti program tahfidz (menghafal Al-Qur'an). Metode ini dilakukan secara satu persatu santri berhadapan langsung untuk menyetorkan hafalannya kepada guru atau insteruktur dengan tanpa harus dibatasi berapa banyak halaman yang disetorkan kepadanya, tergantung kemampuan dan kemauan dari santri itu sendiri, misalnya; seorang santri hanya mampu menyetorkan satu halaman, maka iapun harus menyetorkan satu halaman tersebut atau seorang santri bisa menghafalkan lebih dari satu halaman, maka iapun tidak pernah dilarang untuk menghafalkan halaman selanjutnya. Namun ada satu catatan yang harus diperhatikan oleh seorang santri yaitu bahwa ia tidak boleh menambah hafalan, sebelum hafalan pada hari sebelumnya betul-betul lancar dan tidak ada yang salah, dan ketika sudah memasuki ruangan untuk menyetorkan hafalannya dihadapan guru atau instruktur, seorang santri boleh membawa atau membaca $\mathrm{Al}$-Qur'an artinya ketika sudah memasuki ruangan yang dimulai jam 06.00 s.d. 09.00 ia boleh membaca Al-Qur'an sambil menunggu antrian. ${ }^{10}$

${ }^{9}$ Hasil wawancara dengan Maunah Usman, wakil ketua asrama Tahfidz PP. Putri Al Munawwir Komplek “Q”, pada tanggal 28 Januari 2004.

${ }^{10} \mathrm{Hasil}$ wawancara dengan Uswatun Khasanah, pengurus seaman Tahfidz PP. Putri Al 
Pelaksanaan metode tahfidz ini bila dilaksanakan dengan jadwal yang tersusun dengan rapi dan terlaksana dengan konsisten, maka akan berhasil dengan baik, dan dapat mencapai target yang telah ditentukan.

\section{Metode Takrir}

Untuk mengetahui pelaksanaan metode takrir di PP. Putri Al Munawwir Komplek "Q", dapat dilihat dari jawaban santri atas pertanyaan kapan anda bertakrir? Mereka memberi jawaban bahwa sebagian santri PP. Putri Al Munawir Komplek "Q" dalam melaksanakan takrir bila sudah siap mencapai $20,34 \%$, sedang setiap hari sebanyak $71,19 \%$, sementara yang dua hari sekali yaitu $8,47 \%$.

Dalam wawancara penulis dengan ketua asrama tahfidz yaitu Siti Rohmah dan wakilnya Maunah Usman, mereka mengatakan bahwa, kegiatan takrir di PP. Putri Al Munawwir Komplek "Q" dilaksanakan agar santri mengulang hafalan yang telah di setorkan di hadapan guru melalui beberapa metode pengajaran sebagai berikut:

\section{Metode Musyafahah}

Metode ini dilaksanakan dengan cara muraja'ah atu tasmi' Al-Qur'an secara berpasang-pasangan, maksudnya adalah santri melantunkan ayat-ayat Al-Qur'an yang telah dihafal dengan maqro' seperempat, dan santri yang lain menyimak bacaannya. Metode ini dilaksanakan setiap malam hari kecuali malam hari jum'at yaitu dilaksanakan pada jam 21.30-22.00.

\section{Metode Kelompok}

Metode ini dilaksanakan dengan cara satu persatu santri berhadapan langsung dengan instruktur untuk mengulang hafalannya yaitu dengan maqro' seperempat juz dan dilaksanakan secara berputar sesuai dengan kelompoknya masing-masing. Diantara kelompok tersebut adalah kelompok satu, kelompok dua, dan kelompok tiga, dengan pengajar tiga ustadzah yaitu ustadzah $\mathrm{Hj}$. Qorri 'Aina, Ustadzah Uswatun Khasanah, dan Ustadzah Siti Rahmah, misalnya; kelompok satu sekarang mengulang hafalannya kepada ustadzah Hj. Qorri 'Aina, kelompok dua mengulang hafalannya kepada ustadzah Uswatun Khasanah, dan kelompok tiga mengulang hafalannya kepada ustadzah Siti Rahmah, maka untuk malam senin selanjutnya kelompok dua mengulang hafalannya kepada ustadzah Hj. Qorri 'Aina, kelompok tiga mengulang hafalannya kepada ustadzah Uswatun Khasanah, dan kelompok satu mengulang hafalannya kepada ustadzah

Munawwir Komplek “Q”, pada tanggal 28 Januari 2004. 
Siti Rahmah. Begitu seterusnya. Metode ini dilaksanakan setiap malam senin yaitu sesudah jama'ah shalat maghrib sampai selesai.

\section{Metode Estafet}

Metode ini dilaksanakan dengan cara santri mengulang hafalannya secara berputar sesuai dengan kelompoknya masing-masing yaitu dengan maqro' setengah juz, misalnya dalam kelompok satu mengulang hafalannya dengan magro' setengah juz, maka setengah juz itu langsung berputar dari satu santri ke santri yang lainnya, dengan diulangi dua kali putaran dan santri yang lain menyimak bacaanbacaannya. Begitu juga kelompok dua dan tiga. Metode ini dilaksanakan guna untuk melancarkan hafalan santri, supaya tidak hilang dari ingatannya. Metode ini dilaksanakan setiap hari ahad sesudah jama'ah shalat subuh sampai selesai.

\section{Metode Semaan}

Semaan tersebut dikelompokkan menjadi empat bagian, dan pelaksanaannya berbeda-beda:

\section{Semaan hari jum'at}

Semaan pada hari jum'at ini dilaksanakan sesudah shalat jama'ah subuh dengan maqro' dua juz untuk dua orang dan dilaksanakan secara bergiliran.

\section{Semaan Sabtu Wage}

Semaan sabtu wage ini dikhususkan bagi santri yang telah khatam dengan maqro' lima juz.

\section{Semaan bulanan}

Semaan ini wajib dilaksanakan bagi seluruh santri tahfidz. Dan bagi santri tahfidz yang belum khatam semaan dengan maqro' satu juz dan apabila lebih itu lebih baik, dan bagi santri yang sudah khatam wajib semaan dengan maqro' lima juz. Semaan ini dilaksanakan hanya satu kali dalam setiap bulannya dan untuk waktunya santri memilih sendiri karena yang terpenting adalah dalam satu bulannya setiap santri wajib semaan. Dan untuk semaan bulan selanjutnya, maka yang dibaca pada bulan kemarinnya juga ikut dibaca lagi.

\section{Per Semester}

Semaan ini dilaksanakan setiap 6 bulan sekali dan masing-masing santri yang sudah hafal diatas juz 10 wajib semaan 5 juz. Dan bagi santri yang baru mendapat hafalan 5 juz kebawah, maka mereka tetap mengikuti metode yang telah disebutkan diatas. 
Metode ini mempunyai tujuan untuk memberi semangat setiap santri yang sudah khatam atau yang belum khatam untuk deresan (mengulang hafalannya) agar bertambah lanyah atau lancar hafalannya dan supaya terbiasa menghafal dihadapan umum atau orang banyak agar tidak grogi, maka untuk membuktikannya dengan melalui deresan (mengulang hafalan) ini. ${ }^{11}$

Untuk mengontrol keaktifan santri penghafal Al-Qur'an dalam mengikuti kegiatan takrir atau tahfidz, pengurus asrama Tahfidz PP. Putri Al Munawwir Komplek "Q" selalu menyediakan daftar hadir santri baik untuk yang bagian setoran maupun yang mengulang. ${ }^{12}$

\section{Frekuensi Menghafal}

Untuk dapat mengetahui frekuensi menghafal Al-Qur'an di dalam satu harinya bagi santri di PP. Putri Al Munawwir Komplek “Q”, maka dapat dilihat dari pertanyaan dalam sehari berapa jam anda gunakan untuk menghafal AlQur'an? Jawabannya menunjukkan bahwa ada 45, 76\% atau sebanyak 27 santri mampu lebih dari dua jam dalam satu kali hafalan (sekali duduk) untuk menghafal, dan ada $23,73 \%$ atau sebanyak 14 santri yang dua jam dalam sekali duduk untuk menghafal, sementara santri yang duduk untuk menghafal selama satu jam sejumlah 30,51\% atau sebanyak 18 santri.

\section{Aplikasi Metode Menghafal Al-Qur'an Bagi Santri di PP. Putri Ali Maksum Krapyak Bantul Yogyakarta}

\section{Macam-macam Metode Menghafal Al-Qur'an}

Untuk lebih memperkuat dalam hasil penelitian ini, dalam menghafal penggunaan metode tahfidz dan takrir sebagaimana disebutkan mereka dalam menjawab pertanyaan metode apa yang anda gunakan dalam menghafal AlQur'an? Sebagai jawaban bahwa yang menggunakan metode tahfidz saja adalah 9,84\%, metode takrir 13,11\%, metode keduanya adalah 77,05\%.

Berdasarkan hasil jawaban tersebut, maka dapat disimpulkan bahwa santri PP. Putri Ali Maksum menggunakan metode tahfidz dan takrir dalam menghafal Al-Qur'an.

${ }^{11}$ Hasil wawancara dengan Siti Rahmah, ketua asrama tahfidz PP. Putti Al-M.unawwir Komplek “Q”, pada tanggal 28 Januari 2004.

${ }^{12}$ Hasil Wawancara dengan Uswatun Khasanah, Pengurus Semaan Asrama Tabfidz PP. Putri Al Munawwir Komplek “Q”, pada tanggal 28 Januari 2004. 


\section{Metode Tahfidz}

Untuk dapat mengetahui santri dalam menghafal Al-Qur'an di PP. Putri Ali Maksum dapat dilihat dari jawaban santri atas pertanyaan kapan anda bertahfidz? Mereka memberi jawaban bahwa sebagian besar santri PP. Putri Ali Maksum dalam menyetorkan hafalannya yaitu setelah mereka siap, dalam arti guru dan santri. Guru siap menyimak setoran dan santri siap menyetorkan hafalannya mencapai $13,11 \%$, setiap hari sebanyak $59.02 \%$, dan dua hari sekali yaitu $27,87 \%$.

Dalam wawancara penulis dengan ketua asrama tahfidz yadu Nur Khoiriyah, dia mengatakan bahwa pelaksanaan metode tahfidz dalam PP. Putri Ali Maksum melalui beberapa metode pengajaran adalah sebagai berikut:

\section{Metode Binnadzri}

Adalah metode membaca Al-Qur'an dengan melihat mushaf. Metode ini dilaksanakan sebelum santri menghafal Al-Qur'an, maka seorang santri apabila ingin megikuti program hafalan harus mengikuti metode binnadzri terlebih dahulu. Dan metode ini dilaksanakan dengan cara santri membaca Al-Qur'an di hadapan seorang guru atau instruktur dengan melihat Al-Qur'an dan AlQur'an yang digunakan oleh para santri baik yang pra menghafal Al-Qur'an atau yang sudah menghafal Al-Qur'an dengan menggunakan Al-Qur'an standar atau Al-Qur'an pojok yaitu yang dikenal dengan istilah Bariyah.

Metode ini berfungsi untuk mengenalkan kapada para santri yang ingin menghafal Al-Qur'an yaitu mengenai makharijul huruf, sifatul huruf sehingga sesuai dengan kaidah ilmu tajwid. Metode di atas dianggap sebagai salah satu metode yang efektif untuk tahap awal sebelum seorang santri menghafal Al-Qur'an. Sehingga seorang santri apabila sudah mempunyai niat untuk menghafalkan Al-Qur'an, ia sudah fasih atau benar bacaannya dan makharijul hurufnya serta sifatul hurufnya. Pengajar metode Binnadzri ini adalah $\mathrm{Hj}$. Lutfiyah.

\section{Metode Musyafahab}

Metode ini dilaksanakan setelah santri mendapatkan izin dari pengasuh untuk mengikuti program menghafal Al-Qur'an. Metode ini dilakukan dengan cara, lima orang-lima orang santri berhadapan langsung dengan seorang instruktur untuk menyetorkan hafalannya dengan tanpa harus dibatasi berapa, banyak halaman yang disetorkan kepadanya, tergantung kemampuan dan kemauan dari santri itu sendiri, misalnya; seorang santri hanya mampu menyetorkan satu halaman, maka iapun harus menyetorkan satu halaman tersebut atau 
seorang santri bisa menghafalkan lebih dari satu halaman, maka iapun tidak pernah dilarang untuk menghafalkan halaman selanjutnya. Namun ada satu catatan yang harus diperhatikan oleh seorang santri yaitu bahwa la tidak boleh menambah hafalan, sebelum hafalan pada hari sebelumnya betul-betul lancar dan tidak ada yang salah, dan ketika sudah memasuki ruangan untuk menyetorkan hafalannya dihadapan guru atau instruktur, seorang santri tidak boleh membawa atau membaca Al-Qur'an artinya ketika sudah memasuk ruangan yang dimulai jam $06.00 \mathrm{~s} / \mathrm{d} 07.00$ ia harus sudah siap untuk menyetorkan hafalannya. Bagi yang tidak siap untuk menyetorkan hafalannya, maka santri harus mengulang hafalannya yang sudah disetorkan pada hari kemarin. Dan apabila santri telat memasuki ruangan untuk menghafal Al-Qur'an, maka ia tidak boleh masuk ruangan. Yang diharapkan dalam metode ini adalah yang terpenting seorang santri hadir dalam ruangan meskipun hanya mengulang hafalannya yang kemarin. Metode ini dilakukan untuk melatih kedisiplinan santri dalam menialankan kewajibannya sebagai seorang penghafal Al-Qur'an. Pengajar metode ini adalah Ustadzah Hj. Durroh Nafisah.

\section{Berdo’a}

Bagi setiap santri yang akan memulai atau mngakhiri hafalannya dituntut untuk membaca shalawat terlebih dahulu, kemudian diiringi dengan membaca do'a.

\section{Metode Takrir}

Untuk memngetahui pelaksanaan metode takrir di PP. Putri Ali Maksum dapat dilihat dari jawaban santri atas pertanyaan kapan anda bertakrir? Mereka memberi jawaban bahwa sebagian santri PP. Putri Ali Maksum dalam melaksanakan takrir bila sudah siap ada $32,79 \%$, sedang yang melaksanakan takrir setiap hari sebanyak 55,74\%, yang dua hari sekali yaitu $11,48 \%$. Metode takrir yang ada di PP. Putri Ali Maksum dilaksanakan setiap malam hari yaitu mulai jam 18.30-19.30 dengan menyetorkan seperempat juz kepada Hj. Ida Rufaida (putra ke empat dari enam bersaudara KH. Ali Maksum dan Hi. Hasyimah, ini bagi santri yang sudah hafal 5 juz ke atas, dan yang bare hafal juz $1 \mathrm{~s} / \mathrm{d}$ juz 4 tidak mengikuti takrir, tetapi mereka harus mengikuti program tartil bersama-sama dengan dipimpin oleh santri yang mempunyai suara bagus dan sudah mendapat kepercayaan dari pengasuh tahfidz. Santri yang sudah mendapat kepercayaan itu di antaranya yaitu Lilik.

Hal ini sudah sesuai dengan ketentuan bahwa bila pagi harinya setor hafalan kepada Hj. Durroh Nafisah (putra ke lima dari KH. Ali Maksum dengan $\mathrm{Hj}$. Hasyimah) yaitu mulai jam $06.00 \mathrm{~s} / \mathrm{d}$ jam 07.00, maka malam 
harinya dipakai untuk bertakrir, dengan demikian semakin banyak bertakrir, maka akan semakin kuat daya ingat hafalan tersebut.

Dalam wawancara penulis dengan ketua asrama tahfidz PP. Putri Ali Maksum yaitu Nur Khoiriyah, dia mengatakan bahwa kegiatan takrir di PP. Putri Ali Maksum dilaksanakan agar santri mengulang hafalan yang telah di setorkan di hadapan guru melalui beberapa metode pengajaran sebagai berikut:

\section{Metode Musyafabah}

Metode ini dilaksanakan dengan cara muraja'ah atu tasmi' Al-Qur'an secara satu per satu santri berhadapan langsung dengan salah satu santri menyimak bacaannya. Metode ini dilaksanakan setiap malam hari kecuali malam hari jum'at yaitu dilaksanakan pada jam 20.00-21.00.

\section{Metode Kelompok}

Metode ini dilaksanakan dengan cara seluruh santri berkumpul menjadi satu dalam ruangan atau majlis dengan mengulang hafalannya secara bergantian yaitu santri menghafalkan bertatap muka secara bergantian (estafet) dengan magro’ dua juz. Metode ini dilaksanakan pada pagi hari mulai jam 03.30-04.30.

\section{Semaan}

Metode ini dikhususkan bagi santri yang telah khatam 30 juz dan untuk setiap semaannya santri menghafalkan dua juz-dua juz dengan disimak oleh seluruh santri tahfidz dan masyarakat sekitarnya. Metode semaan ini dilaksanakan setiap satu bulan sekali tepatnya pada hari jum'at legi dan bertujuan untuk melatih santri agar terbiasa menghafal dihadapan orang banyak.

Metode ini mempunyai tujuan untuk melatih setiap santri yang sudah khatam agar bertambah lanyah atau lancar hafalannya dan supaya terbiasa menghafal dihadapan umum atau orang banyak agar tidak grogi. ${ }^{13}$

\section{Frekuensi Menghafal}

Untuk dapat mengetahui frekuensi menghafal Al-Qur'an di dalam satu harinya bagi santri di PP. Putri Ali Maksum, maka dapat dilihat dari pertanyaan angket dalam sehari berapa jam anda gunakan untuk menghafal Al-Qur'an? Jawabannya menunjukkan bahwa ada 31,15\% atau sebanyak 19 santri mampu lebih dari dua jam dalam satu kali hafalan (sekali duduk) untuk menghafal, dan ada $42,62 \%$ atau sebanyak 26 santri yang dua jam dalam sekali duduk untuk

${ }^{13}$ Hasil wawancara dengan Nur Khoiriyah, ketua asrama Tahfidz PP. Putri Ali Maksum, pada tanggal 30 Januari 2004. 
menghafal, sementara santri yang duduk untuk menghafal selama satu jam ada $26,23 \%$ atau berjumlah 16 santri.

\section{Perbedaan dan Persamaan Metode Menghafal AI Qur'an di PP. Putri Al Munawwir Komplek “Q” dan PP. Putri Ali Maksum}

Dari beberapa pengamatan dan penelitian yang penults lakukan, maka penulis telah menemukan beberapa persamaan dan perbedaan yang nampak diantara kedua lembaga tersebut. Perbedaan dan persamaan tersebut adalah sebagai berikut:

\section{Perbedaan-perbedaannya}

Yang menjadi perbedaan antara kedua lembaga tersebut terletak pada pelaksanaan metode menghafal AI Qur'an.

PP. Putri AI Munawwir Komplek “Q”

Untuk meningkatkan kwalitas hafalan menggunakan metode pengajaran Qiro'ati, Bin Nadzor juz 1, dan menghafal juz 'Amma, metode ini dilaksanakan juga untuk mengetahui tingkat kemampuan santri mengenai makhorijul hurufnya, sifatul hurufnya. Sehingga diharapkan nantinya santri dapat menghafal Al-Qur'an dengan baik dan benar. Metode ini sebagai langkah awal untuk mengikuti program tahfidz Al-Qur'an yang diterapkan di PP. Putri Al Munawwir Komplek “Q”. dan metode musyafahah, metode ini dilaksanakan secara satu persatu santri berhadapan langsung untuk menyetorkan hafalannya kepada guru atau instruktur.

Untuk melatih kwalitas kelancaran hafalan dengan menggunakan metode musyafahah, metode ini dilaksanakan dengan cara muraja'ah atau tasmi' AlQur'an secara berpasang-pasangan dengan maqro' seperempat juz, metode kelompok, metode ini dilaksanakan secara satu persatu santri berhadapan langsung untuk mengulang hafalannya kepada guru atau instruktur secara berputar sesuai dengan kelompoknya masing-masing dan dilaksanakan hanya sekali yaitu pada malam hari senin dengan maqro' seperempat juz, metode estafet, metode ini dilaksanakan dengan cara santri mengulang hafalannya secara berputar sesuai dengan kelompoknya masing-masing yaitu dengan maqro' setengah juz dan diulangi dua kali putaran, dan metode istima'i (semaan). Pelaksanaan metode tersebut dilakukan dengan cara santri sering semaan, akan tetapi mereka hanya semaan di dalam Pondok saja.

Frekuensi santri dalam menghafal Al-Qur'an sebesar 45,76 \% atau sebanyak 27 santri lebih dari dua jam dalam sekali duduk untuk menghafal, 
dikarenakan sebagian besar dari mereka yang menghafal Al-Qur'an adalah mahasiswa.

\section{PP. Putri Ali Maksum}

Untuk meningkatkan kwalitas hafalan menggunakan metode pengajaran binnadzri (membaca Al-Qur'an dengan melihat mushaf), metode ini dilaksanakan sebelum santri menghafal Al-Qur'an, untuk melatih kelancaran membaca Al-Qur'an sekaligus untuk mengenalkan hokum-hokum bacaan yang terkandung didalamnya, mengenalkan bagaimana tata cara menghafal Al-Qur'an, metode ini sebagai langkah awal untuk mengikuti program tahfidz Al-Qur'an yang diterapkan di PP. Putri Ali Maksum dan metode musyafahah metode ini dilaksanakan secara lima orang-lima orang santri berhadapan langsung untuk menyetorkan hafalannya kepada guru atau instruktur.

Untuk melatih kwalitas kelancaran hafalan dengan menggunakan metode musyafahah, Metode ini dilaksanakan dengan cara santri menghafal sate persatu Idihadapan guru atau instruktur secara bergantian bagi santri yang sudah hafal 5 juz keatas dengan maqro' seperempat juz dan bagi santri yang barn hafal sampai juz 4 hanya diwajibkan mengikuti program tartil bersamasama, dengan dipimpin oleh santri yang mempunyai suara bagus dan sudah mendapat kepercayaan dari pengasuh tahfidz, metode kelompok, metode ini dilaksanakan dengan cara seluruh santri berkumpul menjadi satu dalam ruangan atau majlis dengan mengulang hafalannya secara, bergantian yaitu santri menghafalkan bertatap muka secara bergantian (estafet) dengan maqro' dua juz, metode istima'i (semaan) dan berdo'a. Pelaksanaan metode istima’i dilakukan dengan cara santri sering semaan di berbagai acara seperti acara pernikahan, tasyakuran dan acara-acara hari besar Islam. Metode ini untuk melatih agar santri terbiasa menghafal Al-Qur'an dihadapan orang banyak. Sedangkan metode berdo'a sebagai salah satu penunjang (amalan batin) agar dimudahkan dalam menghafal Al-Qur'an dan terjaga dari kelupaan. Sedangkan mengulang hafalan tetap menjadi usaha lahir yang harus di tempuh seorang penghafal Al-Qur'an. Jadi dua metode tersebut berjalan bersama-sama.

Frekuensi santri dalam menghafal Al-Qur'an sebesar 42,62\% atau sebanyak 26 santri dua jam dalam sekali duduk untuk menghafal, dikarenakan sebagian besar dari mereka yang menghafalkan Al-Qur'an adalah pelajar. Dan pondok ini mengelola lembaga formal sendiri seperti; MTs, MA baik MAK maupun MAU. 


\section{Persamaan-persamaan}

PP. Putri Al Munawwir komplek "Q" dan PP. Putri Ali Maksum merupakan dua lembaga yang memiliki latar belakang sama yaitu sama-sama bergerak di bidang pendidikan non formal, keduanya sama-sama mengelola madrasah tahfidz Al-Qur'an, sehingga tidak heran jika santri yang menetap pada lembaga tersebut terdapat santri yang menghafal Al-Qur'an tetapi sekaligus sekolah pada lembaga formal seperti MTs (Madrasah Tsanawiyah), MA (Madrasah Aliyah), SMU (Sekolah Menengah Umum), dan bahkan banyak yang kuliah di berbagai Perguruan Tinggi yang tersebar di Kota Yogyakarta.

Dalam mengelola madrasah tahfidz, metode yang diterapkan dalam proses menghafalkan Al-Qur'an kedua lembaga tersebut sama-sama menggunakan metode tahfidz dan takrir.

\section{Faktor yang Mendukung dan yang Menghambat Menghafal Al-Qur'an di PP. Putri Al Munawwir dan PP. Putri Ali Maksum}

Faktor yang mendukung dan yang Menghambat menghafal di PP.Putri Al Munawwir Komplek " $Q$ "

Faktor yang Mendukung dalam Menghafal Al-Qur'an

Untuk mengetahui tujuan santri PP. Putri Al Munawwir Komplek "Q" dalam menghafal Al-Qur'an dapat dilihat dari pertanyaan apa yang menjadi tujuan pokok anda menghafal Al-Qur'an? Sebagai jawabannya dapat diketahui bahwa sebagian santri PP. Putri Al Munawwir Komplek "Q" yang mempunyai tujuan semata-mata beribadah pada Allah ada 23,71\%, turut melestarikan kemurnian Al-Qur'an ada 8,47\%, dan yang mempunyai tujuan keduanya sebanyak $67,80 \%$. Dari analisa jawaban para santri yang telah tersebut di atas dapat di ambil suatu kesimpulan bahwa tujuan santri PP. Putri Al Munawwir Komplek "Q" dalam menghafal Al-Qur'an adalah semata-mata beribadah pada Allah dan turut melestarikan kemurnian Al-Qur'an 67, 80\%. Faktor-faktor tersebut adalah alat pendidikan yang dipergunakan untuk memudahkan santri dalam menghafal Al-Qur'an di PP. Putri Al Munawwir Komplek "Q".

Menurut ketua asrama tahfidz yaitu Siti Rohmah, dia mengatakan bahwa disamping mereka menghafal Al-Qur'an saja juga ada yang kuliah dan bekerja. Sehingga mereka harus mampu mengantisipasi memilih waktu yang berbeda-beda menurut individu masing-masing. ${ }^{14}$ Hal ini dapat terbukti dalam pertanyaan untuk menghafal Al-Qur'an kapan anda memilih waktu? Jawabannya

${ }^{14}$ Hasil wawancara dengan Siti Rahmah, ketua asrana Tahfidz PP. Putri Al Munawwir Komplek “Q”, pada tanggal 28 Januari 2004. 
bahwa santri PP. Putri Al Munawwir Komplek “Q” yang menyatakan ketika ada waktu sebanyak $49,15 \%$, di saat pikiran sedang tenang ada $44,07 \%$, yang memilih setelah shalat wajib ada $6,78 \%$.

Selain waktu yang mempengaruhi untuk menghafal Al-Qur'an, situasi dan kondisi juga turut mempengaruhi keberhasilan santri dalam mencapai sesuatu yang dimaksud. Bila situasinya baik artinya situasi yang mendukung kelancaran jalannya proses belajar mengajar, maka juga akan dapat mendukung.

Untuk mengetahui situasi dan kondisi yang ada di PP. Putri Al Munawwir Komplek "Q" dalam menghafal Al-Qur'an dengan melalui jawaban responden atas pertanyaan angket bagaimana situasi dan kondisi PP. Putri Al Munawwir Komplek "Q" untuk menghafal Al-Qur'an? Mereka menyatakan jawabannya bahwa yang menyatakan situasi dan kondisinya sangat mendukung ada $27,12 \%$, dan mendukung sebanyak $47,46 \%$, sedangkan $25,42 \%$ santri menyatakan kurang mendukung.

Faktor yang Menghambat dalam Menghafal Al-Qur'an

Kesulitan dalam menghafal Al-Qur'an, amok lebih jelasnya mengenai pernah dan tidaknya santri PP. Putri Al Munawwir Komplek "Q" mengalami kesulitan akan terlihat dari jawaban mereka atas pertanyaan apakah anda mengalami kesulitan dalam menghafal Al-Qur'an? Mereka memberi jawaban bahwa santri PP. Putri Al Munawwir Komplek "Q" yang menyatakan mengalami kesulitan ada 25,42\%, yang jarang mengalami kesulitan ada $13,56 \%$, yang kadang-kadang mengalami kesulitan sebanyak $61,02 \%$.

Untuk mengetahui penyebab kesulitan dalam menghafal Al-Qur'an di PP. Putri Al Munawwir Komplek "Q" dapat dilihat dari jawaban responden atas pertanyaan jika anda mengalami kesulitan faktor apa yang jadi penyebab? sebagai jawabannya bahwa yang menyatakan penyebab kesulitan menghafal karena banyak ayat yang hampir sama ada $28,81 \%$, dan tidak dapat konsentrasi sebanyak 50,85\%, dan 20,34\% menyatakan karena gangguan lingkungan.

Untuk dapat mengetahui langkah apa yang ditempuh oleh santri PP. Putri Al Munawwir Komplek “Q” dalam menghadapi kesulitan tersebut dapat dilihat dari laporan pertanyaan langkah apa yang anda tempuh dalam menghadapi kesulitan? Hasil jawaban menunjukkan bahwa langkah yang ditempuh santri PP. Putri Al Munawwir Komplek "Q" dalam menghadapi kesulitan yaitu $66,10 \%$ mengulangi menghafal dan $10,17 \%$ menanyakan pada guru dan teman, sementara santri yang menyatakan harus instropeksi diri ada $23,73 \%$.

Dengan demikian dapat dikatakan bahwa usaha yang ditempuh santri PP. Putri Al Munawwir Komplek "Q" ini dalam menemui kesulitan sewaktu 
menghafalkan Al-Qur'an adalah dengan mengulangi kembali hafalannya sebesar 66,10\%.

\section{Faktor yang Mendukung dan yang Menghambat dalam Menghafal Al- Qur'an di PP. Putri Ali Maksum}

Faktor yang mendukung dalam Menghafal Al-Qur'an

Untuk mengetahui tujuan santri PP. Putri Ali Maksum dalam menghafal Al-Qur'an dapat dilihat dari pertanyaan apa yang menjadi tujuan pokok anda menghafal Al-Qur'an? Sebagai jawabannya dapat diketahui bahwa sebagian santri PP. Putri Ali Maksum yang mempunyai tujuan semata-mata beribadah pada Allah ada 11,48\%, sedang turut melestarikan kemurnian Al-Qur'an ada $22,95 \%$, dan yang mempunyai tujuan keduanya sebanyak $65,57 \%$. Dari analisa jawaban para santri tersebut di atas dapat di ambil suatu kesimpulan bahwa tujuan santri PP. Putri Ali Maksum dalam menghafal Al-Qur'an adalah semata-mata beribadah pada Allah dan turut melestarikan kemurnian Al-Qur'an sebanyak $65,57 \%$.

Menurut ketua asrama tahfidz yaitu Nur Khoiriyah, dia mengatakan bahwa disamping mereka menghafal Al-Qur'an saja juga ada yang sekolah dan kuliah. Sehingga mereka harus mampu mengantisipasi dalam memilih waktu, dan tentunya setiap individu mempunyai waktu yang berbeda-beda. Hal ini dapat terbukti dalam item pertanyaan untuk menghafal Al-Qur'an kapan anda memilih waktu ? Jawabannya dapat di ketahui bahwa sebagian santri PP. Putri Ali Maksum yang menyatakan ketika ada waktu 36,07\%, di saat pikiran sedang tenang sebanyak 59,02 \%, dan yang memilih setelah shalat wajib ada $6,78 \%$.

Untuk mengetahui situasi dan kondisi yang ada di PP. Putri Ali Maksum dalam menghafal Al-Qur'an dengan melalui jawaban responden atas pertanyaan angket bagaimana situasi dan kondisi PP. Putri Ali Maksum untuk menghafal Al-Qur'an? Mereka menyatakan bahwa santri PP. Putri Ali Maksum yang menyatakan situasi dan kondisinya sangat mendukung ada $32,79 \%$, dan yang mendukung ada $22,95 \%$, serta yang kurang mendukung sebanyak $44,26 \%$ santri.

Faktor yang Menghambat dalam Menghafal Al-Qur'an

Kesulitan dalam menghafal Al-Qur'an, untuk lebih jelasnya mengenai pernah dan tidaknya santri PP. Putri Ali Maksum mengalami kesulitan akan terlihat dari jawaban mereka atas pertanyaan apakah anda mengalami kesulitan dalam menghafal Al-Qur'an? Mereka memberi jawaban bahwa santri PP. Putri 
Ali Maksum yang menyatakan mengalami kesulitan ada 36,07\%, yang jarang mengalami kesulitan ada $24,59 \%$, dan yang kadang-kadang mengalami kesulitan sebanyak $39,34 \%$.

Dan untuk mengetahui penyebab kesulitan dalam menghafal Al-Qur'an di PP. Putri Ali Maksum dapat dilihat dari jawaban responden atas pertanyaan jika anda mengalami kesulitan faktor apa yang jadi penyebab? sebagai jawabannya bahwa yang menyatakan penyebab kesulitan menghafal karena banyak ayat yang hampir sama ada 21,31\%, dan tidak dapat konsentrasi sebanyak 59,02\%,dan yang 19,67\% menyatakan karena gangguan lingkungan.

Sedangkan untuk dapat mengetahui langkah apa yang ditempuh oleh santri PP. Putri Ali Maksum dalam menghadapi kesulitan tersebut dapat dilihat dari laporan pertanyaan angket langkah apa yang anda tempuh dalam menghadapi kesulitan? Hasil jawaban menunjukkan bahwa langkah yang ditempuh dalam menghadapi kesulitan yaitu 37,70\% mengulangi menghafal dan $26,23 \%$ menanyakan pada guru dan teman, dan yang menyatakan harus instropeksi diri ada 36,07\%.

Dengan demikian dapat dikatakan bahwa usaha yang ditempuh santri PP. Putri Ali Maksum ini dalam menemui kesulitan sewaktu menghafalkan AlQur'an adalah dengan mengulangi kembali hafalannya sebanyak 37,70\% santri.

\section{Hasil Yang Dicapai Dalam Menghafal Al-Qur'an di PP. Putri Al Munawwir Komplek “Q” dan PP. Putri Ali Maksum}

Hasil yang dicapai dalam menghafal Al-Qur'an santri PP. Putri Al Munawwir Komplek “Q” berbeda-beda, hal ini terbukti dengan hasil jawaban mereka atas pertanyaan berapa halaman yang dapat anda hafal dalam sehari? yaitu di dalam satu hari jumlah hafalan yang dicapai mereka kebanyakan tidak tentu, yaitu sebanyak 64,41\% santri, karena memang kemampuan mereka tidak sama, dan yang mendapatkan satu halaman ada $27,12 \%$ santri, sedang yang mendapatkan dua halaman $8,47 \%$ santri. Dengan jumlah halaman yang mereka hafal dalam sehari-harinya tidak tentu sebanyak 64,41\%,akan tetapi meraka belum berani disimak secara glondongan

Sedangkan hasil yang dicapai dalam menghafal Al-Qur'an oleh santri PP. Putri Ali Maksum juga berbeda-beda, hal ini terbukti dengan hasil jawaban mereka atas pertanyaan berapa halaman yang dapat anda hafal dalam sehari? yaitu yang tidak tentu ada sebanyak 65,57 santri, yang mendapatkan satu halaman ada 24,59\% santri, dan yang mendapatkan dua halaman 9,84\% santri. Akan tetapi walaupun dengan jumlah halaman yang mereka hafal dalam sehariharinya tidak tentu $65,57 \%$, meraka berani disimak secara glondongan. 


\section{KESIMPULAN}

Berdasarkan pemaparan, uraian dan hasil analisa tentang sumber data yang didapatkan penulis dalam penelitian mengenai Studi Komparatif Tentang Metode Menghafal Al-Qur'an Antara PP. Putri Al Munawwir Komplek "Q" dengan PP. Putri Ali Maksum Krapyak Bantul Yogyakarta adalah sebagai berikut:

Perbedaan dan Persamaan metode menghafal Al-Qur'an di PP. Putri Al Munawwir Komplek "Q" dan PP. Putri Ali Maksum yaitu: Persamaannya yaitu sama-sama menggunakan dua metode yakni metode tahfidz (menghafal) dan metode takrir (mengulang). Sedangkan perbedaannya adalah dalam penerapannya, kalau di PP. Putri Al Munawwir Komplek "Q" penerapannya menggunakan 4 metode yaitu metode Qiro'ati, metode menghafal juz 'Amma, metode Bin nadzor juz 1, metode musyafahah dengan satu persatu, metode ini untuk kwalitas hafalan. Sedangkan untuk kelancaran hafalan menggunakan empat metode yaitu metode musyafahah dengan berpasangan, metode kelompok, metode estafet, dan metode semaan.Sedangkan di PP. Putri Ali Maksum menggunakan 2 metode yaitu metode Binnadzri, metode musyafahah dengan lima orang-lima orang, metode ini untuk kwalitas hafalan. Sedangkan untuk kelancaran hafalan mengunakan 4 metode yaitu metode musyafahah dengan satu persatu, metode kelompok, metode Istima'i (semaan), dan metode berdo'a sebagai penunjang kelancaran hafalan.

Faktor yang mendukung dalam menghafal Al-Qur'an PP. Putri Al Munawwir Komplek "Q" yaitu; semata-mata beribadah pada Allah dan turut melestarikan kemurnian Al-Qur'an 67,80\%, waktu yang dipilih untuk menghafal ketika ada waktu sebanyak 49,15\%, serta situasi dan kondisi mendukung sebanyak 47,46\%. Sedangkan di PP. Putri Ali Maksum; semata-mata beribadah pada Allah dan turut melestarikan kemumian Al-Qur'an sebanyak 65,57\%, waktu yang dipilih untuk menghafal di saat pikiran sedang tenang sebanyak $59,02 \%$, serta situasi dan kondisi kurang mendukung sebanyak 44,26\%. Faktor yang menghambat dalam menghafal Al-Qur'an di PP. Putri Al Munawwir Komplek "Q"; kadang-kadang mengalami kesulitan sebanyak 61,02\% santri dikarenakan tidak dapat konsentrasi sebanyak 50,85\% santri sehingga mereka mengulangi kembali hafalannya sebesar 66,10\% santri. Sedangkan PP. Putri Ali Maksum kadang-kadang mengalami kesulitan sebanyak 39,34\% santri dikarenakan tidak dapat konsentrasi sebanyak 59,02\%,santri sehingga mereka mengulangi kembali hafalannya sebesar 37,70\%

Hasil yang dicapai dalam menghafal Al-Qur'an di PP. Putri Al Munawwir Komplek "Q" dalam sehari-harinya tidak tentu sebanyak 64,41\% santri karena 
memang kemampuan mereka tidak sama sehingga mereka belum berani untuk disimak secara glondongan. Sedangkan di PP. Putri Ali Maksum halaman yang mereka hafal dalam sehari-harinya tidak tentu $65,57 \%$ santri, mereka sudah berani untuk disimak secara glondongan.

\section{DAFTAR PUSTAKA}

Al Hafidz Abi Muhammad Zakiyuddin Abdul Adzim bin abdul Qowi alMundziri, 1993, Targhib Wa Tarhib Jilid 2, Beirut: Dar Al-Fikr.

Departemen Agama Republik Indonesia, 1985, Al-Qur'an dan Terjemahnya, Proyek Pengadaan Kitab Suci Al-Qur'an, Jakarta.

Sutrisno Hadi, 1998, Metodologi Research Jilid II, Yogyakarta: Andi Offset. Anas Sudijono, 1992, Pengantar Statistik Pendidikan, Jakarta: Rajawali.

Muhammad Zein, 1975, Metodologi Pengajaran Agama, Yogyakarta: AK. Group \& Indra. 